\title{
FROM BLACK HOLE TO THE PEARL OF THE MEDITERRANEAN: A NEW IDEA OF NATION FOR INDEPENDENT MONTENEGRO
}

ABSTRACT After the separation from Serbia following a referendum in 2006, the Republic of Montenegro started rebuilding its international image by reinventing its past and present. In fact, through an extensive campaign in both foreign and domestic media, the government attempted to change the perception of Montenegro's history, focusing especially on the difference between Serbs and Montenegrins. This is understandable considering the minimal numeric superiority of those in favour of the independence, where the national factor was the main determinant. The image of the new Montenegrins, also in light of Montenegro's route to joining the EU, must be detached from Serbia's problems (- such as Kosovo) and must divert attention from the ever-growing problem of international criminal traffic. One of the most emblematic examples of such recreation of virtue are the commercials for Montenegrin tourism, inviting to explore ancient forests, enjoy traditional food and experience "Montenegrin hospitality": the aim is to send a positive message of non-nationalistic, Europe-friendly ethnicity. The purpose is also for Montenegro to be perceived as serene, as opposed to the ex-partner country, seen largely as wildly nationalistic and ethnically obsessed: therefore, a new form of "soft" ethno-cultural image has been introduced, incorporating only the best and cleverly minimizing the "non-acceptable" aspects of its culture and history.

Keywords: Nationalism, identity, nation, tourism, ethnicity 
fter the separation from Serbia following a referendum in 2006, the Republic of
Montenegro started rebuilding its international image by reinventing its past and present. In fact, through an extensive campaign in both foreign and domestic media, the government attempted to change the perception of Montenegro's history, focusing especially on the difference between Serbs and Montenegrins. It is well known that there can be no nation without history: this concept could easily be applied and translated into an immediate post-2006 attempt to "clean up" Montenegro's image, in order to distance the country from the intrinsically ethnically-coated past within and after Yugoslavia. The old Yugoslavia was long gone and the new Serbia-Montenegro union was a residue of a shared heritage and past, ready to be dismantled. The battle between the two sides of Montenegro - those in favour and those against its independence - truly shows just how closely bound were the concepts of nationality and ethnicity. The situation was simplified in the following manner on the BBC News website on May 22 ${ }^{\text {nd }}$ 2006: [...] The pro-independence camp insisted that Montenegro was being held back by its association with Serbia. Those in favour of preserving the union pointed to the strong historical links between Montenegrins and Serbs. [...] Generally, most ethnic Montenegrins and the Montenegrin government backed the drive to independence. The ethnic minorities were seen as mostly in favour of the independence, though some had expressed doubts over their status in an independent Montenegro. [...] Those against the independence tend to identify themselves as ethnically Serbian and saw no real distinction between Serbs and Montenegrins. ${ }^{1}$

One of the best examples that explain the need for the distancing of Montenegro from Serbia can be found in The politics of symbol in Serbia by I. Colović: [...] The myth of national identity does not content itself with discourse about difference, nor is the problem of that myth reduced to the fact that it exaggerates the differences between peoples, bringing them into a state of irreconcilable antagonism. [...] Serbia and its culture are something special, something apart, but not in the same way that every other nation is. Its special character is not relative, but absolute. [...] Serbia is the only country consistently true to its self, capable of shaping that self as original and unique. ${ }^{2}$

Serbia's national identity overshadowed any other characteristic the country may have had during the Bosnian war, sadly rising to international fame as an example of "ethnic identity gone bad". Together with the recent Kosovo issue, which in 2006 was still an "issue" and not yet an independent state to deal with, there were enough reasons to take the newly arisen opportunity and to recreate history in order to provide Montenegro with a different future. The ties with the difficult Balkan past appeared to have been finally broken, and there was no trace of "Yugo-nostalgia", which is so typical of today's Balkans: it was all about the future, mostly for the younger genera-

Article available at 'Q\&A: Monteregno Referendum', BBC News, 22 May 2006, at < http://news.bbc. co.uk/2/hi/europe/4994212.stm>.

2 I. Čolović, The Politics of Symbol in Serbia. Essays on Political Anthropology, trans. by C. Hawkesworth, London 2002, p. 66. 
tions but also something that could possibly give back dignity and pride to the elderly Montenegrins.

Absurdly, even though the Montenegrin referendum was won mainly by abundant use of the promise of the European Union and its attractiveness (it had been one of the main points of the pro-independence parties: giving a chance for a better future to the young generations, up to then completely excluded and black-listed from the "real" Europe, meaning the EU), the independence itself goes exactly against the principle of "united" Europe by bringing further separation into an already divided and problematic part of the continent. In fact, the EU was never exceedingly thrilled about the prospect of the referendum, which was however granted by the constitution of the State Union of Serbia and Montenegro and therefore could not be directly denied. In the aftermath of the final scission of the Yugoslav relic, Winston Churchill's famous words The Balkans produce more history than they can consume appeared to be ominously true: the burden of the past was going to be the first thing to be forgotten as quickly as possible. But how? What route was this newly created state of Montenegro going to take?

From a European point of view, especially considering the EU, insistence on "heavy nationalism" was not going to be useful or could be deemed "acceptable". Generally speaking, the Balkans were finally coming to terms with the changes that had happened both within the ex-Yugoslav countries and the rest of the world, and a clear need of a new image for all of the republics emerged. A "softer" version of history, polished and void of all the negative characteristics related to the war period was to become the main goal: more so in the case of Montenegro, where the close result of the referendum (with only about 2,000 votes making the difference) was evidence of a thoroughly divided country with two strong identities and no chance of finding common ground considering that the main divide was the outcome of the referendum itself.

In order to understand the danger of the post-referendum situation, there are some facts to be considered. The 55 per cent threshold set by the EU was a gamble that could well have ended up creating an additional source of instability in the western Balkans precisely at the time when the international community needed to concentrate its resources on the resolution of Kosovo's status. Had the referendum result ended in the "grey" zone between 50 and 55 per cent, Montenegro's government would have been legally unable to declare independence. At the same time it would have viewed the referendum result as a mandate to further weaken the State Union. The unionists would have considered the result as a victory and demanded immediate parliamentary elections and closer ties with Belgrade. The resulting dissonance between Belgrade and Podgorica would have created a crisis of legitimacy that would have been a significant distraction from the Kosovo status process.

The EU, OSCE and many neighbouring countries have congratulated Montenegro on the free and fair manner in which the referendum was conducted and expressed their satisfaction with the high turnout. But the referendum left Montenegro deeply divided. Of the more than 44 per cent who voted for retaining the State Union, many belonged to the 30 per cent of the population who defined themselves as Serbs. This 
hardcore nationalist grouping showed no promise of ever completely coming to terms with the country's independence.

The remaining 14 per cent probably voted more out of practical or sentimental reasons, and would have probably adapted shortly to Montenegro's new status. The government extended an olive branch, with the most prominent politicians publicly saying they intended to treat every Montenegrin citizen as if he/she voted for independence. Of course, there was also an urgent need to separate the fate of Montenegro and Kosovo, and that could be achieved more easily if Montenegro was independent.

So, could Montenegro's independence have undermined the development of democracy in Serbia? Would it have destabilized further the already precarious situation in the Union? Those were realistic fears.

For Serbia to become a true factor in the matter of regional stability, it had to define its borders and concentrate more on its own issues, while repairing damaged relations with its neighbours. This was likely to happen only if and when Serbia's attention was turned away from Kosovo, Montenegro and Bosnia (The Republic of Srpska issue). Therefore, the new state of Montenegro had the seal of approval from the EU also as a potential resolution to an unbearable situation.

In light of these considerations, what was the easiest way for the Montenegrin referendum winners to show they were in the right and to present Montenegro as a friendly state devoid of any danger? Some of the most emblematic examples of such recreation of virtue are the commercials and the websites designed to promote Montenegrin tourism, and also some new phenomena such as ethno/eco villages.

\section{THE AFTERMATH OF THE REFERENDUM AND THE NEW FREEDOM: THE CASE OF BUDVA}

Economically, Montenegro was already de facto the "biggest" (ironically, considering its actual dimensions) off-shore state of Europe. Infamous because of its corruption and the grey market, that was actually the main employment market for the population, the lack of laws aiming with real effort to eradicate corruption and illegality, and the numerous arrivals of businessmen of dubious legality from countries such as Russia and Italy, Montenegro was almost hailed as the new Montecarlo, where it was possible to gamble both in a casino and in business. In fact, immediately after the referendum, there was a real boom in the real estate field: it was easy to understand why. Due to its stunning natural environment, noticeable especially in the Bay of Kotor, where mountains and sea are joined in an incredible union, and the low prices when compared to the rest of seaside Europe, Montenegro became the favourite target for foreign investors, particularly Russians. ${ }^{3}$ Complicated Montenegrin laws made it impossible for foreigners to have real estate property inside the country without having

J. Gilić, Montenegro, corsa agli immobili, Osservatorio Balcani e Caucaso, 12 December 2006, at <http:// www.balcanicaucaso.org/aree/Montenegro/Montenegro-corsa-agli-immobili-35373 >. 
a registered society: therefore, there was a boom of newly created business associations which were sometimes false and created ad hoc in order to purchase, but most of the times also brought real business. The main concern at the time was the impact that these developments would have on the economy and environmental resources: in fact, the whole coastal area changed greatly because of new constructions and gigantic investments that not always respected the style and the natural characteristics of the surrounding environment. The most obvious case is that of the city of Budva: once a peaceful and charming small town, it became the epicentre of nightlife, and its appearance changed quite rapidly because of the 'Environmental plan of the $\mathrm{Mu}$ nicipality of Budva.' Presented as the regulation plan for new constructions, it actually changed the purpose of various building sites, ruining natural greenery in favour of high-end, exclusive buildings for a rich clientele. Budva was presented as the new Monte Carlo, with plans for hotels and casinos, and a lot of potential for tourism and consequent economic gain.

If the goal was to create a modern city suitable for a high-end, elite clientele, its realisation was far from easy. In fact, Montenegro's tourism in that particular area was not remotely luxurious, and was still based on private accommodation with no regulation whatsoever. For decades it was considered a family-friendly holiday destination, with budget-friendly prices and a "homely" feel to it. However, as soon as foreign investors got in, the lack of regulation and the high level of corruption produced a true reign of chaos. Thus Budva became famous not only as the capital of Montenegrin tourism, but also as the main space for construction abuse and excessive urbanisation. ${ }^{5}$

In its attempt to break free from the past and to open its doors to foreign investors, who were perceived as those who could save the failing economy and provide jobs for the local population, rules were bent at every occasion. The only positive side effect of the "Russian wave" was the fact that when it came to money, all ethnic and identity tensions disappeared.

\section{A SUSTAINABLE KIND OF TOURISM: ETHNO-VILLAGES FOR A "POSITIVE ETHNIC" IMPRINT}

Partially due to the wave of enthusiasm resulting from the independence and the consequent need for a positive type of affirmation and presentation, but also because of a local need for employment in areas not easily reachable or simply economically ignored, there has been a true boom of the "ethno" trend in the last few years. When it comes to tourism in today's global world, it is understandable that any kind of originality is viewed with curiosity, and with the right kind of support from the media or simply by

L. Zanoni, Salvare Budva dalla speculazione edilizia, Osservatorio Balcani e Caucaso, 22 August 2011, at <http://www.balcanicaucaso.org/aree/Montenegro/Salvare-Budva-dalla-speculazione-edilizia-99265>.

5 Idem, Le sfide di Budva: turismo e urbanizzazione, Osservatorio Balcani e Caucaso, 4 August 2011, at $<$ http://www.balcanicaucaso.org/aree/Montenegro/Le-sfide-di-Budva-turismo-e-urbanizzazione-99258>. 
following other travellers' feedback from websites such as the world-famous Tripadvisor, any destination can go from unknown to highly desirable.

Montenegro's history is not particularly original, yet is exotic enough to be considered worth knowing: for instance, one could mention the the royal family or the traditional tales of bravery and heroism that are so characteristic to the Balkans, the wonderful traditional clothes and of course the national cuisine, simple yet captivating.

Montenegro's economy is clearly divided between the north and the south of the country. In fact, the coastal area always had its tourism and obvious environmental attractions, and in recent years started attracting cruise ships coming to the Bay of Kotor, and also private luxury boats that now can find suitable ports and all the accompanying services for a richer clientele. In contrast, the north remained isolated from this kind of market, and unluckily has very few establishments that cater to winter activities such as skiing or snowboarding - despite the fact that the Montenegrin mountains are quite spectacular and never lack snow during the season. Additionally, due to the lack of proper roads infrastructure that could help the local population during the winter (it is a common situation to be cut off from the rest of the world, with no electricity or fresh food because the vehicles cannot pass through), those of working age are forced to seek employment in bigger cities and therefore have to move elsewhere, leaving only the elder members of the family behind. However, the frail economy and the global crisis opened up other perspectives: using the local characteristics in order to produce employment and gather interest in otherwise depressed areas. The idea was a winner: not only the pre-existing rural and/or ruined buildings could be put to use with little investment, there was also no age limit for those who could take part in these activities - on the contrary, the elderly could bring the country's traditions and the consequent feeling of authenticity that could really attract tourists. Thus, by taking advantage of the local agriculture and farming in order to create small restaurants that could offer local specialties unavailable in other places, using sustainable building material and employing local staff during construction, ${ }^{6}$ providing basic yet captivating accommodation with a low impact on the surrounding environment, and, finally, focusing on the conservation and promotion of the local tradition: in a relatively short period, the interest of the population in the previously depressed areas had been definitely roused.

It is a little known fact in the world, but ever since 1991 Montenegro has been an "ecological state" by its own decree, produced on September $20^{\text {th }}$ of the same year, committing to protect its environment "to the highest level" : We, Members of Parliament of the Republic of Montenegro, are aware that in view of the threat to nature, protecting the identity of the land in which we live and work has become our most immediate and pressing task. Bearing in mind our debt to nature, which is a source of health and our inspira-

S. Lješkovic Mitrović, ECO Lodge koncept u Crnoj Gori. ECO Lodge concept in Montenegro, Podgorica 2007, p. 17.

'Country Profile (Montenegro)', European Environment Agency, 26 November 2010, at <http:// www.eea.europa.eu/soer/countries/me/soertopic_view?topic=country\%20introduction $>$. 
tion for freedom and culture, we are devoting ourselves to its protection for the sake of our survival and the future of our posterity.

We recognize that all our differences are less important than the changes to the environment we live in. Regardless of our national, religious, political and other sentiments and convictions, we are fully aware that the dignity and wellbeing of a human being are intrinsically connected with the wellbeing and purity of nature.

Human beings and the natural world around them are one in their depth, meaning and denotation.

Thus the abuse of man has always entailed the abuse of nature. Being committed to the struggle for the dignity of man, we are also called upon to struggle for the dignity of nature. By adopting the Declaration, Montenegro defines its attitude towards nature as a state policy and calls upon all people to show wisdom and prevent the impending ecological catastrophe.

This declaration was ambitious and the intentions behind it were good: in fact, even during the Yugoslavia years, Montenegro was considered the "wild" republic with a wild beauty, famous for its mountains (the country's very name means "black mountain") and the stunning seaside, both relatively untouched and truly "natural". However, today's Montenegro falls short of such promise and the only remaining "wild" environment is in the commercials broadcasted on main world channels in order to attract tourists. The reality is less glamorous and more down-to-earth, and is clearly described in the country's profile at the EEA (European Environment Agency) website?: the main issues are the negative trend showing loss of agricultural land (especially in touristic zones, where it is destined to wild construction, often with no law application whatsoever), the hugely augmented maritime traffic that obviously has a negative impact on the local environment (the most obvious case being the Bay of Kotor and the cruise ships that come and go daily in season), and even the tourism itself has issues, such as water problems (well known at the seaside, chronic and unresolved due to lack of funds) and waste disposal. Also, there is no real ecological conscience in the population: there is no strict regimen regarding waste disposal and recycling, which would be the first logical local step towards the elimination of garbage in open areas. In fact, there is a noticeable absence of any kind of population education regarding environmental issues: there are organisations trying to act locally, but in the author's personal experience, they are usually labelled as "time wasters" and "useless and boring" - a truly ironic attitude coming from the citizens of the only ecological state in the world.

When it comes to the ethno-villages, another name that emerged for these recent phenomena is "eco-village" and the latter is less significant than it should be when the whole phenomenon is analysed. At the very beginning, when they first started to appear, the accent was on the local cuisine and zero-km ingredients provided in situ, guaranteed to be genuine. The ethnic component was present yet did not prevail: however,

8 'Declaration concerning the ecological state of Montenegro', ESE, at <http://siba-ese.unisalento.it/ index.php/traterraemare2/article/view/10779/9952>.

9 'Country Profile (Montenegro)'... 
as the political and social situation progressed, the potential of the "exotic" Montenegrin tradition (or at least exotic in the eyes of the wealthy Western tourists) was undeniable. Therefore, instead of being revitalized (meaning re-valued and re-built) the villages became reminiscent of the scenery in spaghetti westerns: visibly fake, even exaggerated, mixing all kinds of ethnic props (from WW2 firearms and pieces of uniforms, to "made in China" Montenegrin flags and traditional clothes) and de facto inventing another type of staged ethno feeling. The author himself has visited quite a few of these "staged" villages, where the guests could get the distinct feeling of fake patriotism and history being reinvented and almost glamorised; this could be characterized as an attempt to obtain genuine rural feeling that failed because the commercial motivation prevailed and gave no real, authentic result.

How is it possible that something this easy - using pre-existing history and places in order to highlight the "good ethnicity" factor in Montenegro - could backfire and result in cheap imitations that could easily belong in a low budget movie? If we consider the theory that sees tourism as the sale of identity (which is what distinguishes one country from another, one destination from another), given the rich history of Montenegro, full of legends and fascinating stories and its unique nature, this chance should have been seen for what it was, a splendid occasion to promote positive national identity, devoid of any negative characteristics associated with the war years, giving economic benefits and employment to depressed and forgotten areas. Yet perhaps the fever of wanting to produce too much and too soon, the lack of supervision from the authorities and ignorance of rules that should be implemented strictly in order to avoid exaggeration, have produced chaos in the ideas of those involved, while actual experts in ethnology and history, or environmental activists, have never even been approached. Therefore, even in the attempt to highlight a certain type of identity, other fake identities were produced and are now permanent. The main issue appears to be the conflict between commercial needs (these projects are usually financed by private investors, with non-existent supervision and often complete disregard of the law due to the corruption problems plaguing the country), according to which the words "more ethnicity" are understood as "better ethnicity", even if it is "made in China" and clearly fake, and the need to act in order to preserve the "right" kind of identity which usually is done through official organisations and with the aid of experts. In an ideal situation, the best solution would be to give value to pre-existing constructions and environmental possibilities, with the support and financial aid of the State through experts' help, and it is easy to see that such projects would surely attract funds from the European Union, who is always involved in helping small but environmental-friendly ideas.

However, the subject of ethnicity in a young state that obtained its independence in a truly controversial situation, with its population divided into two fractions (Serbian and Montenegrin), is so convoluted that even the concept of ethnicity related to food can become a source of problems. In fact, in July 2012 there was the outrageous case of Milo Kadija, the owner of the ethno village "Kadmi" in Njeguši: he refused to serve a nun from the Serbian Orthodox Church, a friend of hers and 5 little children, because he chose not to open his business to those belonging to the Serbian ethnicity. 
The case received ample coverage in newspapers and on television, resulting in an escalation of threats, physical damage to the restaurant, much tension between the two opposing parties, and, finally, the closure of the ethno-village, apparently due to the lack of proper permits and papers necessary to operate in the sector. ${ }^{10}$

This event particularly highlighted the problems between the Serbian Orthodox Church that has existed for decades in Montenegro, and the recently reactivated Montenegrin Orthodox Church: these two fractions are clearly defined by politics and are full of violently ethnic characteristics, instead of being defined by religion. In fact, in the same article VestiNet reports the claims of the Serbian Church, saying that it is no wonder this happens while the Government itself supports the hate wave towards the Holy Serbian Church. ${ }^{11}$

\section{THE BLACK MOUNTAIN, THE BLACK HOLE AND THE TRUE PEARL OF THE MEDITERRANEAN: THE CLOSE RELATIONSHIP BETWEEN TOURISM AND IDENTITY}

The two main examples of the Montenegrin response to the political changes in country, namely, national and social circumstances, have both been closely examined. On the one hand, there is the wild construction in Budva, aiming to transform the once ancient town into a brand new, luxurious and worldly destination, so very similar to many other cities, well-known to the "rich and famous". Once freedom was gained through the 2006 referendum, the weight of the consequences has led to desperate attempts to modernise and globalise through modern architecture with no regard whatsoever for the past, opening doors and welcoming Russian investors (in 2011, Montenegrin newspapers reported that around $60 \%$ of the state's coast was owned by Russians ${ }^{12}$ ), and giving into the general chaos of debts, corruption, lack of legality. On the other hand, there are the depressed and forgotten areas, often rural and lacking in infrastructure, seeing a new chance for "redemption" through the wave of identity fashion. Identity: this is the keyword to understanding the Balkans, and therefore understanding the recent developments in Montenegro. This concept is brilliantly explained by Maria Todorova: In a less analytical vein, a popular if unedifying stereotype portrays the Balkans as a region cursed with too much history per square mile, with an excess of historical memory, protracted hatreds, and a proliferation of obstinate and incompatible ethnic and religious identities. ${ }^{13}$

Tourism can be compared to shopping for certain brands: the only difference is that usually countries represent objects known for certain characteristics. Italy has ancient ru-

\footnotetext{
10 'Skandal u Crnoj Gori dobija epilog: zatvoreno Kadijino etno selo', Vestinet, 1 August 2012, at <http:// www.vestinet.rs/u-fokusu/skandal-u-crnoj-gori-dobija-epilog-zatvoreno-kadijino-etno-selo>.

11 Ibid.

12 J. Pavičić, 'Mediterraneo: camera senza vista', Lettera Internazionale, Vol. 114 (2012), p. 42.

13 M. Todorova, Balkan Identities. Nation and Memory, London 2004, p. 2.
} 
ins and churches, Greece has its temples and the sirtaki, Spain has corridas and flamenco: what does Montenegro have? Caught between the aftermath of a Yugoslav past, where it played a minor role and was always the underdeveloped and "savage" republic, and the newly found freedom, it finally caught up with modern times, and the outcome was discouraging. In fact, its economical fragility and the internal chaos from a social and legislative point of view exclude any kind of uniqueness or attractiveness except for its natural beauty - which could and will become its brand. Yet even the very meaning of the word brand contradicts the genuine characteristics of identity: a brand is built, programmed, constructed in detail, while identity should be spontaneous and "felt". The danger is that while attempting to build a brand (namely giving Montenegro precise features that will unequivocally distinguish it at first sight from other destinations in the Mediterranean) the fine line between this new version of the country and its true identity will be crossed, and the artificiality of the result will be a deterrent to tourists instead of a magnet. Considering the fact that both fiction and identity are necessary, it is up to the local population to avoid making fake ethnic details (such as in the previously mentioned case of ethnic villages) or reinventing history completely (as was the case in Budva).

The real question of Montenegrin identity is truly a complex matter and has been researched thoroughly by experts and scientists around the world with much success. The present paper does not aim to resolve whether this identity has scientific and historical grounds: it is a given fact that it now exists, whether it is by acceptance or by history. In the midst of an identity crisis such as the post-referendum years, the historical theories stemmed from Montenegro's nationalism, and in the same time the nationalism itself provided the basis for and reinforced the embellishment of history. ${ }^{14}$ The ties between nationalism and the state are clearly expressed by Milton J. Esman: The core of nationalist ideology is the conviction that the nation and the state that represents that nation embody the people's deepest and most abiding values and virtues, that the destiny of individuals is indissolubly linked to the fate of their nation, and that consequently they owe the nation their undivided loyalty and devotion. ${ }^{15}$

\section{CONCLUSIONS}

Considering all of the above, it may be said that the north and the south of Montenegro, also due to their very different characteristics regarding economy and tradition, have taken two very different approaches to tourism as a way of embodying Montenegrin identity. The coastal area is slowly killing the old version of its touristic traditions, which used to be centred around the small, family-run businesses of private owners. These businesses are now bound to disappear as they are no match for the Goliaths that are the big hotels and corporations. It is interesting to notice how a recent James Bond movie con-

14 A. Cattaruzza, Territoire et nationalisme au Montenegro. Les voies de l'indépendance, Paris 2012, p. 60 (Géographie et Cultures. Culture et Politique).

15 M.J. Esman, An Introduction to Ethnic Conflict, Cambridge 2004, p. 41. 
tributed to this kind of image: one of the main scenes sees Bond in a Montenegrin casino, presumably in the city of Budva (despite the fact that it was actually filmed in the Czech Republic) and displays in full screen one of the proudest and the most obvious symbols of Montenegro, its flamboyant red and gold flag. There is nothing in this scene that could resemble the old Yugoslav times which are very much alive in real life: Bond even arrives to the coast in a state-of-the-art super fast train, which is as far as possible from Montenegro's reality as can be. We could say that the coast has now an identity of its own while not having it altogether: it is a mixture of wild construction, newly built luxury hotels with adequate clientele, the remaining small domestic businesses and foreign investors. It is rare to see any kind of ethnic display except for the obligatory flags on government buildings, and it certainly is not encouraged: modernity is the key, but all along there has been no indication of what exactly this modernity should be.

On the contrary, the north has decided to embrace the Montenegrin heritage made up of heroism, tales, antique firearms and folkloristic clothes and music, by revitalizing the old buildings in disuse or building new ones in an ecological spirit (with various degrees of success and authenticity). There is much more respect for nature and its power in the mountains than at the seaside: that is partially due to the fact that the north is still less publicized and less promoted, and, one could say, a less obvious choice, attracting eco-tourists and mountain lovers. The main issues are always the lack of proper roads and infrastructure, but there are very little funds and the government is absent, favouring other priorities. Therefore, it becomes really easy to exaggerate in the attempt to be authentic and original in order to attract foreign tourists that discover Montenegro for the first time: in this case, identity and ethnicity becomes almost a matter of humour, confirming all the popular jokes regarding Montenegrins (quite the pop-culture phenomena). However, this is still a positively perceived sort of nationalism, very mild and not intimidating at all, we could say almost family-friendly, and therefore by all means commercial.

Unfortunately, both of these solutions to the issue of promotion of the "new" Montenegro appear to lose touch with reality, forgetting their native characteristics while chasing what they believe to be their future. It could be only a matter of time before what used to be typical of Montenegro's various regions will transform into a standard tourist destination, offering nothing different from any other Balkan country with a similar environment and a shared - even though differently described - history. In other words, for every aspect of local authenticity (which along with others forms a unique mosaic) that disappears in favour of "modernity", a part of the authentic Montenegrin identity becomes artificial, transforming a black hole into a pearl, but so very similar to thousands of other pearls around the world.

\section{BIBLIOGRAPHY}

Cattaruzza A., Territoire et nationalisme au Montenegro. Les voies de l'indépendance, Paris 2012 (Géographie et Cultures. Culture et Politique).

'Country Profile (Montenegro)', European Environment Agency, 26 November 2010, at 
<http://www.eea.europa.eu/soer/countries/me/soertopic_view ?topic=country\%20introduction $>$.

'Declaration concerning the ecological state of Montenegro', ESE, at < http://siba-ese.unisalento.it/index.php/traterraemare2/article/view/10779/9952>.

Esman M.J., An Introduction to Ethnic Conflict, Cambridge 2004.

Gilić J., Montenegro, corsa agli immobili, Osservatorio Balcani e Caucaso, 12 December 2006, at <http://www.balcanicaucaso.org/aree/Montenegro/Montenegro-corsa-agli-immobili-35373>.

Čolović I., The Politics of Symbol in Serbia. Essays on Political Anthropology, trans. by C. Hawkesworth, London 2002.

Lješkovic Mitrović S., ECO Lodge koncept u Crnoj Gori. ECO Lodge concept in Montenegro, Podgorica 2007.

Pavičić J., 'Mediterraneo: camera senza vista', Lettera Internazionale, Vol. 114 (2012).

Perica V., Balkan Idols. Religion and Nationalism in Yugoslav States, Oxford-New York 2002 (Religion and Global Politics).

'Q\&A: Monteregno Referendum', BBC News, 22 May 2006, at <http://news.bbc.co.uk/2/hi/ europe/4994212.stm>.

'Skandal u Crnoj Gori dobija epilog: zatvoreno Kadijino etno selo', Vestinet, 1 August 2012, at <http://www.vestinet.rs/u-fokusu/skandal-u-crnoj-gori-dobija-epilog-zatvoreno-kadijino-etno-selo>.

Todorova M., Balkan Identities. Nation and Memory, London 2004.

Todorova M., Imagining the Balkans, New York-Oxford 1997.

Volcic Z., Serbian Spaces of Identity. Narratives of Belonging by the last "Yugo" Generation, New York 2011.

Zanoni L., Salvare Budva dalla speculazione edilizia, Osservatorio Balcani e Caucaso, 22 August 2011, at <http://www.balcanicaucaso.org/aree/Montenegro/Salvare-Budva-dalla-specula zione-edilizia-99265>.

Zanoni L., Le sfide di Budva: turismo e urbanizzazione, Osservatorio Balcani e Caucaso, 4 August 2011, at <http://www.balcanicaucaso.org/aree/Montenegro/Le-sfide-di-Budva-turismo-e-urbanizzazione-99258>.

Prof. Antonio VIOLANTE teaches in the Department of Cultural Heritage and Environment at the University of Milan, Italy. 